\title{
SIMPLEKS DAN MULTIPLEKS PRE-ENRICHMENT-PCR UNTUK DETEKSI Salmonella Enteritidis DAN Typhimurium PADA KARKAS AYAM
}

\author{
[Simplex and Multiplex Pre-Enrichment-PCR for Salmonella Enteritidis and \\ Typhimurium Detection from Chicken Carcasses]
}

\author{
Siti Nurjanah ${ }^{1,2) \star}$, Winiati P. Rahayu ${ }^{1,2)}$, Ratih Dewanti-Hariyadi ${ }^{1,2)}$, Ni Gusti Ayu Made \\ Widyatari Asthiti ${ }^{1)}$, dan Rahadina Praba Melati ${ }^{1)}$ \\ 1) Departemen IImu dan Teknologi Pangan, Fakultas Teknologi Pertanian, IPB University, Bogor \\ 2) South East Asian Food and Agricultural Science and Technology (SEAFAST) Center, IPB University, Bogor
}

13 November 2020 / Disetujui 27 November 2021

\begin{abstract}
A PCR assay has been developed and applied to detect Salmonella contamination in chicken carcasses. However, a concentration fewer than 3 cells per gram lead to false-negative results due to difficulties in the DNA extraction. The objective of this study was to evaluate of the influence of preenrichment on the sensitivity of simplex and multiplex PCR methods the detection of for Salmonella spp., $S$. Enteritidis and S. Typhimurium in chicken carcasses. Artificial contamination was done using very low number of Salmonella Hadar, S. Enteritidis dan S. Typhimurium and pre-enrichment was carried out by 8 hours incubation in non-selective (BPW) medium. The results showed that simplex PCR could detect Salmonella spp., S. Enteritidis and S. Typhimurium at initial numbers of 2.3, 0.9 and $2.3 \mathrm{MPN} / \mathrm{mL}$ of cells in broth medium, respectively. A multiplex PCR could detect mixed culture of the three Salmonella serovars at an initial number of $0.73 \mathrm{MPN} / \mathrm{mL}$ of cells. When compared to non-enrichment treatment, simplex pre-enrichment-PCR gave an increase in the percentage of positive results in chicken carcasses ( $n=12$ ), from 75 to $100 \%$ for Salmonella spp., from 8 to $58 \%$ for S. Typhimurium, and from 58 to $75 \%$ for S. Enteritidis. Increasing in the positive percentage was also occurred at multiplex pre-enrichment-PCR, however the concentration of S. Enteritidis primer was not optimum for detection. Pre-enrichment step significantly increases the sensitivity of PCR-based assay for detection Salmonella.
\end{abstract}

Keywords: chicken carcass, PCR, pre-enrichment, Salmonella Enteritidis, Salmonella Typhimurium

\begin{abstract}
ABSTRAK
Metode PCR telah dikembangkan dan diaplikasikan untuk mendeteksi cemaran Salmonella spp. pada karkas ayam. Cemaran Salmonella spp. dengan jumlah di bawah 3 sel per gram dapat menimbulkan kesalahan negatif analisis karena kesulitan mendapatkan ekstrak DNA. Tujuan penelitian ini untuk melihat pengaruh perlakuan pre-enrichment pada sensitivitas metode analisis simpleks dan multipleks PCR untuk deteksi Salmonella spp., Salmonella Enteritidis dan Salmonella Typhimurium pada karkas ayam. Konfirmasi limit deteksi dilakukan dengan kontaminasi artifisial Salmonella Hadar, $S$. Enteritidis dan $S$. Typhimurium dengan jumlah yang sangat rendah dan pre-enrichment dilakukan pada media cair nonselektif Buffered Peptone Water (BPW) yang diinkubasi selama 8 jam. Hasil penelitian menunjukkan bahwa simpleks pre-enrichment-PCR mampu mendeteksi Salmonella spp., $S$. Enteritidis dan $S$. Typhimurium pada jumlah awal 2,3; 2,3; dan 0,9 MPN/mL. Multipleks dapat mendeteksi campuran bakteri tersebut pada jumlah awal $0,73 \mathrm{MPN} / \mathrm{mL}$. Dibandingkan dengan tanpa enrichment, simpleks preenrichment-PCR memberikan peningkatan persentase hasil positif Salmonella spp., dari 75 menjadi 100\%, positif $S$. Typhimurium dari 8 menjadi $58 \%$, dan positif $S$. Enteritidis dari 58 menjadi $75 \%$. Peningkatan presentase hasil positif juga terjadi pada multipleks pre-enrichment-PCR, namun penggunaan konsentrasi primer $S$. Enteritidis belum mampu mendeteksi serovar tersebut secara optimal. Dapat disimpulkan bahwa penggunaan tahap pre-enrichment dapat meningkatkan sensitivitas metode PCR secara signifikan.
\end{abstract}

Kata kunci: karkas ayam, PCR, pre-enrichment, Salmonella Enteritidis, Salmonella Typhimurium

\footnotetext{
*Penulis Korespondensi: E-mail: sity_nr@apps.ipb.ac.id
} 


\section{PENDAHULUAN}

Karkas ayam merupakan komoditi daging dengan tingkat konsumsi yang tinggi di Indonesia. Berdasarkan hasil Survei Konsumsi Bahan Pokok (VKBP) tahun 2017 dan Survei Sosial Ekonomi Nasional (Susenas) tahun 2019 yang dilaksanakan BPS RI, konsumsi daging ayam ras adalah sebesar $12,79 \mathrm{~kg} / \mathrm{kapita} / \mathrm{tahun}$ (Kementan, 2020), dengan penggunaan untuk konsumsi langsung, HOREKA (hotel, restoran, kafe) dan industri. Data produksi yang tercatat di BPS tahun 2020 sebesar 3,3 juta ton. Karkas ayam yang dijual di Indonesia belum lepas dari bahaya bakteri Salmonella spp. (Bakara et al., 2014). Penelitian Safitri et al. (2019) menunjukkan sebanyak $32,14 \%$ (9 dari 28 sampel) karkas ayam dari pasar tradisional di Pangkal Pinang tercemar Salmonella spp. Salmonella spp. merupakan bakteri penyebab penyakit salmonellosis yang merupakan foodborne diarrheal disease dan bersifat zoonosis. Sumber utama infeksi Salmonella spp. berasal dari pangan hewani seperti babi, unggas, dan hewan ternak (Eng et al., 2015). Keberadaan Salmonella spp. dapat menjadi indikator higienitas pengolahan ayam potong (Utari et al., 2016). Jenis Salmonella spp. yang paling banyak menginfeksi manusia adalah jenis $S$. Typhimurium dan $S$. Enteritidis dengan prevalensi infeksi sebesar $79 \%$ dari total infeksi Salmonella di dunia (WHO, 2014).

Karakterisasi risiko Salmonella spp. mencemari daging ayam dapat dilakukan melalui deteksi keberadaan Salmonella spp. beserta identifikasi serotipenya pada karkas ayam. Karakterisasi risiko digunakan untuk membuat skala prioritas berdasarkan jenis risiko dari serotipe Salmonella. Serotipe yang berbeda dapat menimbulkan gejala yang berbeda, sebagai contoh $S$. Typhimurium yang dapat menunjukkan gejala penyakit baik pada manusia dan ayam sedangkan $S$. Enteritidis hanya menunjukkan gejala penyakit pada manusia dan tidak menunjukkan gejala pada ayam (Crump dan Wain, 2017). Keberadaan asymptomatic carrier tersebut dapat mempersulit kontrol dalam pencegahan infeksi (Maciel et al., 2011). Kuantifikasi selanjutnya dapat dilakukan terhadap risiko tersebut sehingga tindakan pencegahan dapat dapat dilakukan lebih efektif. Oleh karena itu, karakterisasi risiko membutuhkan metode deteksi cepat dan spesifik seperti PCR (polymerase chain reaction). Metode PCR menggunakan prinsip penggandaan DNA secara in vitro sehingga ketika divisualisasi dengan gel elektroforesis dapat terlihat pita dari DNA tersebut (kualitatif) yang dapat dibedakan berdasarkan mobilitas fragmen DNA (Radji et al., 2010; Triyani et al., 2016). Primer spesifik untuk $S$. Typhimurium digunakan adalah STM4497 yang merupakan bagian dari gen penyandi fimbrial yang diduga kuat merupakan gen protein pada sitoplasma $S$. Typhimurium (TortajadaGenaro et al., 2015). Sistem multipleks digunakan untuk mendeteksi beberapa strain sekaligus dalam satu kali reaksi PCR, sehingga dapat diketahui serotipe Salmonella dengan cepat.

Deteksi Salmonella spp. menggunakan PCR pada sampel bahan pangan memerlukan adanya tahapan enrichment karena pada umumnya protokol PCR memerlukan konsentrasi mikroorganisme target yang sangat tinggi yang biasanya diperoleh hanya setelah pengayaan sampel (Myint et al., 2006). Metode deteksi menggunakan PCR pada Salmonella spp. yang dilakukan tanpa pre-enrichment membutuhkan konsentrasi mikroorganisme awal yang tinggi agar dapat terdeteksi yaitu $10^{4}$ $10^{5}$ sehingga dapat menimbulkan kesalahan analisis negatif (Afendy dan Son, 2012; Saeki et al., 2012; Yosua, 2018). Salmonella tidak dapat berkompetisi dengan baik terhadap bakteri-bakteri perusak yang mengontaminasi pangan, oleh karena itu berdasarkan ISO 6579 (2017) tahap enrichment dalam media non-spesifik Buffered Peptone Water (BPW) atau disebut juga tahap pre-enrichment dibutuhkan untuk membantu memperbaiki sel bakteri yang rusak, melarutkan zat penghambat atau zat toksik lainnya, dan juga menyediakan kecukupan nutrisi khususnya bagi Salmonella. BPW mengandung pepton sebagai sumber nutrisi berupa nitrogen, karbon, vitamin, dan mineral serta $\mathrm{NaCl}$ untuk mempertahankan keseimbangan osmotik dan fosfat sebagai buffer (Taskila et al., 2012). Deteksi dengan kuantifikasi dapat dilakukan dengan menggunakan quantitatif PCR atau realtime PCR (Nurjanah et al., 2018).

Kemampuan deteksi adalah parameter penting untuk metode deteksi bakteri secara kualitatif dan akan meningkat dengan memberikan kesempatan sel memperbanyak diri pada perlakuan prapengayaan atau pre-enrichment. Dalam penelitian ini kemampuan deteksi ditentukan dengan pengujian sejumlah sampel dan dinyatakan dengan persentase positif terhadap jumlah sampel total. Tujuan penelitian ini untuk mengukur peningkatan kemampuan deteksi PCR terhadap Salmonella Enteritidis dan Salmonella Typhimurium secara simpleks dan multipleks dengan perlakuan pre-enrichment.

\section{BAHAN DAN METODE}

\section{Bahan}

Bahan dalam penelitian ini adalah karkas ayam ras (dalam kondisi segar) yang diperoleh dari pasar swalayan dan pasar tradisional di daerah Bogor digunakan untuk tahapan evaluasi sensitivitas dan sampel analisis untuk tahapan aplikasi metode deteksi. Bakteri utama yang digunakan untuk penentuan limit deteksi antara lain Salmonella enterica subspesies Hadar (BCC B2908) dari Balai Besar 
Penelitian Veteriner (Bbalitvet) yang mewakili jenis Salmonella spp. selain $S$. Typhimurium dan $S$. Enteritica, S. Typhimurium (ATCC 14028) dari Laboratorium Mikrobiologi SEAFAST Center, IPB Bogor, dan S. Enteritidis (ATCC 13076) dari Badan Pengawas Obat dan Makanan (BPOM) yang berupa stock freeze.

\section{Persiapan kultur}

Kultur murni Salmonella yang telah diinkubasi selama 18 jam dan dikonfirmasi jumlah mikroba awalnya. Jumlah yang ditambahkan adalah sebanyak $1 \mathrm{~mL}$ untuk metode simpleks dan total $1 \mathrm{~mL}$ untuk metode multipleks dari masing-masing serovar pengenceran $10^{-9}$ dan $10^{-10}$ yang jumlahnya dikonfirmasi dengan metode MPN 3 tabung. Jumlah awal setelah dikonfirmasi ke dalam Tabel Most Probable Number (MPN) mencapai 0,9-2,3 MPN/mL. Semua sampel kemudian ditambahkan media BPW (Oxoid) sebanyak $225 \mathrm{~mL}$.

\section{Evaluasi sensitivitas deteksi teknik pre- enrichment (Myint et al., 2006)}

Evaluasi sensitivitas deteksi dilakukan dengan: 1) melakukan kontaminasi artifisial, 2) inkubasi selama 8 jam pada $35^{\circ} \mathrm{C}$, dan 3) ekstraksi DNA dari 225 $\mathrm{mL}$ larutan BPW pada sampel daging ayam terkontaminasi artifisial yang telah. Waktu inkubasi 8 jam mengacu pada penelitian Myint et al. (2006), tidak dilakukan optimasi penggunaan waktu inkubasi Kontaminasi artifisial kultur Salmonella dilakukan dengan merujuk pada Myint et al. (2006), yaitu dengan menggunakan $25 \mathrm{~g}$ sampel daging ayam, kemudian didekontaminasi dengan cara dimasukkan ke dalam plastik steril dan dicelupkan ke dalam air mendidih selama 30 detik dan segera didinginkan pada air es. Daging ayam yang telah didekontaminasi sederhana tersebut dilumuri (di-spike) dengan 1 mL kultur yang telah disiapkan (konsentrasi 0,9-2,3 $\mathrm{MPN} / \mathrm{mL}$ ), sehingga diperkirakan cemaran 0,9-2,3 $\mathrm{MPN} / 25 \mathrm{~g}$.

\section{Ekstraksi DNA (Reyes-Escogido et al., 2010; Nurjanah et al., 2017)}

DNA diekstraksi menggunakan metode Chelex100 dengan modifikasi pada waktu pemanasan. Larutan BPW pada sampel kemudian dimasukkan ke dalam tabung sentrifus $50 \mathrm{~mL}$ dan disentrifugasi (kecepatan $805 \mathrm{xg}$, suhu $4^{\circ} \mathrm{C}$, selama 15 menit). Supernatan yang ada sebagian dibuang dan sebanyak $2 \mathrm{~mL}$ sel bakteri yang mengendap (pelet) dipindahkan ke tabung microcentrifuge $2 \mathrm{~mL}$ dan disentrifugasi kembali menggunakan microcentrifuge (Hettich Mikro 22R, DJB LabCare, UK) (kecepatan $6000 \mathrm{xg}$, suhu $4{ }^{\circ} \mathrm{C}$, selama 5 menit). Supernatan kembali dibuang dan pelet diresuspensi dengan $1000 \mu \mathrm{L}$ TE buffer (10 mM TRIS-base (SigmaAldrich) $\mathrm{pH} 7,5 ; 1 \mathrm{mM}$ EDTA $\mathrm{pH} 8,0$ ), lalu divortex hingga homogen. Campuran tersebut kemudian disentrifugasi (kecepatan $8000 \mathrm{rpm}$, suhu $4^{\circ} \mathrm{C}$, selama 5 menit). Pelet yang dihasilkan di-resuspensi dengan $100 \mu \mathrm{L}$ TES buffer lisis (10 mM TRIS-base (Sigma-Aldrich) pH 7,5; 1 mM EDTA pH 8,0;0.5\% SDS), lalu diinkubasi pada suhu $65^{\circ} \mathrm{C}$ selama 5 menit. Kemudian ditambahkan dengan segera 150 $\mu \mathrm{g}$ proteinase-K dan $20 \mu \mathrm{L}$ RNAse. Setelah itu, campuran diinkubasi pada suhu $65^{\circ} \mathrm{C}$ selama 5 menit kemudian pada suhu ruang selama 2 menit. Selanjutnya campuran ditambahkan $150 \mu \mathrm{L}$ campuran 25 mg Chelex-100 dalam buffer TE. Campuran diinkubasi kembali (suhu $65^{\circ} \mathrm{C}$, selama 5 menit), kemudian disentrifugasi (kecepatan 10.000 rpm, suhu $4^{\circ} \mathrm{C}$, selama 5 menit). Lapisan bagian atas diambil secara perlahan dengan mengukur volumenya untuk dipresipitasi dengan sodium asetat $3 \mathrm{M}$ sebanyak $0,1 \times$ volume yang diambil dan etanol $95 \%$ sebanyak $2,5 \times$ volume yang diambil, kemudian campuran diinkubasi pada suhu $-20^{\circ} \mathrm{C}$ selama 20 jam. Setelah itu, DNA disentrifugasi (kecepatan $10.000 \mathrm{rpm}$, suhu $4^{\circ} \mathrm{C}$, selama 10 menit). Pelet yang dihasilkan ditambahkan 500-1000 $\mu \mathrm{L}$ etanol $70 \%$, lalu disentrifugasi kembali (kecepatan 10.000 rpm, suhu $4^{\circ} \mathrm{C}$, selama 10 menit). Supernatan dibuang dan pelet yang dihasilkan dikeringkan pada suhu ruang, lalu dilarutkan dalam 50-100 $\mu \mathrm{L}$ Nuclease Free Water (NFW) (Promega no. katalog P1195). Campuran disimpan sebagai DNA template pada suhu $-20^{\circ} \mathrm{C}$ sampai digunakan untuk analisis dengan PCR.

\section{Simpleks dan multipleks PCR}

Simpleks dengan primer InvA (Soumet et al., 1999), prot6E (Hadjinicolaou et al., 2009) dan STM4497 (Park et al., 2009) masing-masing pada PCR terpisah Salmonella Hadar, Salmonella Enteritidis dan Salmonella Typhimurium seperti tertera dalam Tabel 1, dan multipleks dilakukan dengan campuran tiga primer pada satu tabung PCR, dengan konsentrasi yang berbeda (Tabel 1). Kondisi running PCR (Applied Biosystems GeneAmp 9700 PCR System, USA) adalah pra-denaturasi pada suhu $95^{\circ} \mathrm{C}$ selama 3 menit, denaturasi-annealingekstensi selama 30 siklus dengan suhu dan waktu yang tertera pada Tabel 1, dan diakhiri dengan ekstensi akhir pada suhu $72^{\circ} \mathrm{C}$ selama 5 menit, dengan menggunakan PCR GoTaq Green Master Mix (Geneaid) yang terdiri dari Taq DNA polimerase, $\mathrm{MgCl}$, dan dNTP (masing-masing dATP, dCTP, dGTP, dan dTTP), Nuclease Free Water (NFW).

\section{Aplikasi metode untuk analisis sampel karkas ayam ras (Myint et al., 2006) \\ Deteksi cemaran Salmonella spp. dilakukan pada karkas ayam ras yang diperoleh dari swalayan dan pasar tradisional, dengan jumlah sampel sim- pleks $(n=12)$ dan multipleks $(n=9)$.}


Tabel 1. Kondisi running PCR pada metode simpleks dan multipleks

\begin{tabular}{|c|c|c|c|c|c|c|}
\hline & \multicolumn{3}{|c|}{ Simpleks PCR $^{1}$} & \multicolumn{3}{|c|}{ Multipleks PCR ${ }^{2}$} \\
\hline & $\begin{array}{l}\text { Salmonella } \\
\text { spp. }\end{array}$ & $\begin{array}{c}S . \\
\text { Enteritidis }\end{array}$ & $\begin{array}{c}S . \\
\text { Typhimurium }\end{array}$ & $\begin{array}{l}\text { Salmonella } \\
\text { spp. }\end{array}$ & $\begin{array}{c}S . \\
\text { Enteritidis }\end{array}$ & $\begin{array}{c}S . \\
\text { Typhimurium }\end{array}$ \\
\hline Suhu denaturasi $\left({ }^{\circ} \mathrm{C}\right)$ & 95 & 95 & 95 & & 95 & \\
\hline $\mathrm{Ta}\left({ }^{\circ} \mathrm{C}\right)$ & 58 & $52^{1}$ & $52^{1}$ & & $52^{2}$ & \\
\hline Suhu ekstensi $\left({ }^{\circ} \mathrm{C}\right)$ & 72 & 72 & 72 & & 72 & \\
\hline Target gen & InvA & Prot6E & STM4497 & InvA & Prot6E & STM4497 \\
\hline Primer & ST11-f & $438-f$ & STM4497M2-f & ST11-f & 438-f & STM4497M2-f \\
\hline & ST15-r & $572-r$ & STM4497M2-r & ST15-r & $572-r$ & STM4497M2-r \\
\hline Ukuran (bp) & 429 & 135 & 311 & 492 & 135 & 311 \\
\hline Konsentrasi primer $(\mu \mathrm{M})$ & & 0,500 & & 0,400 & 0,400 & 0,120 \\
\hline
\end{tabular}

Karkas ayam utuh dimasukkan ke dalam plastik steril, direndam dengan $450 \mathrm{~mL}$ BPW, dan didiamkan selama 3-5 menit. Seluruh BPW kemudian dimasukkan ke dalam tabung centrifuge $50 \mathrm{~mL}$. Sebanyak $225 \mathrm{~mL}$ BPW dalam tabung centrifuge 50 $\mathrm{mL}$ diinkubasi pada $35^{\circ} \mathrm{C}$ selama 8 jam sebagai perlakuan dengan pre-enrichment, sementara 225 $\mathrm{mL}$ BPW lainnya langsung dilakukan ekstraksi DNA dengan langkah awal disentrifugasi (kecepatan 3000 rpm, suhu $4^{\circ} \mathrm{C}$, selama 15 menit). Selanjutnya, sebagian supernatan hasil sentrifugasi dibuang dan disisakan 0,5-1,0 mL, lalu dipindahkan dan digabungkan dengan hasil sentrifugasi dari tabung lain ke dalam tabung microcentrifuge $2 \mathrm{~mL}$. Ekstraksi DNA dilakukan terhadap larutan dengan metode Chelex-100, lalu hasil ekstraksi DNA dianalisis dengan PCR (Applied Biosystem), Produk PCR divisualisasi dengan elektroforesis gel (Bio-Rad) menggunakan agarosa $2 \%$ dan pita DNA divisualisasi melalui Geldoc (Bio-Rad).

\section{HASIL DAN PEMBAHASAN}

\section{Sensitivitas metode simpleks}

Karkas ayam yang digunakan dalam penelitian ini mungkin mengandung Salmonella, sehingga dalam mengevaluasi sensitivitas metode dalam mendeteksi Salmonella perlu dihilangkan mikroba tersebut. Adanya mikroba indigenous pada permukaan sampel ayam dapat mengganggu cemaran artifisial yang diinokulasikan secara sengaja sehingga dapat mengganggu proses recovery dalam media enrichment (Matias et al., 2010). Berdasarkan hal tersebut, pada pengujian dengan menggunakan kontaminasi artifisial perlu dilakukan tahap dekontaminasi dan dievaluasi efektivitasnya. Proses dekontaminasi yang dilakukan terhadap sampel karkas ayam dengan pemberian air mendidih $\left(100^{\circ} \mathrm{C}\right)$ selama 30 detik dilanjutkan cold shock pada air es telah efektif menghilangkan bakteri indigenous dari karkas ayam (Data tidak ditampilkan).

Primer telah diuji spesifisitasnya pada penelitian sebelumnya dengan melakukan analisis terhadap sekuen parsial gen yang dihasilkan dan di- konfirmasi dengan sekuen referens pada GenBank (Wulan et al., 2021). Primer tersebut telah merujuk dengan tepat pada serovar Salmonella target, sehingga dalam penelitian ini tidak lagi dikonfirmasi dengan uji serologi.

Konsentrasi Salmonella spp., S. Enteritidis dan $S$. Typhimurium dipersiapkan serendah mungkin dengan melakukan pengenceran (sepersepuluh) secara bertahap sampai 9 dan 10 kali pengenceran. Perhitungan dengan metode MPN 3 seri tabung dilakukan agar mampu mendeteksi jumlah yang rendah dan konversi dalam Tabel MPN menunjukkan jumlah awal Salmonella spp. dan $S$. Enteritidis dengan jumlah 2,3 MPN/mL dan $S$. Typhimurium dengan jumlah 0,9 MPN/mL, yang kemudian dispike ke dalam $25 \mathrm{~g}$ daging ayam. Setelah dilakukan simpleks PCR, ketiga serovar Salmonella dengan konsentrasi tersebut menunjukkan pita elektroforesis dengan amplikon yang sesuai gen target masingmasing, yaitu 429 bp (Salmonella Hadar, yang mewakili genus Salmonella spp.), 135 bp (S. Enteritidis) dan $311 \mathrm{bp}$ (S. Typhimurium) (Gambar 1). Pita spesifik yang baik yaitu terlihat tebal, ukuran yang sesuai target, tidak ada pembentukan primer dimer dan tidak smear (Maksum et al., 2018).

Tahap pre-enrichment di media BPW selama 8 jam pada suhu $35^{\circ} \mathrm{C}$ efektif untuk mendeteksi cemaran Salmonella spp. pada jumlah yang sangat rendah melalui metode simpleks PCR, dibandingkan dengan penelitian Yosua (2018) yang mampu mendeteksi pada limit $10^{3} \mathrm{CFU} / \mathrm{g}$. Hasil tersebut senada dengan penelitian yang dilakukan Krämer et al. (2011) yang menunjukan limit deteksi Salmonella spp. 1,4 CFU/10 g menggunakan metode PCR dengan tahap pre-enrichment 8 jam.

\section{Sensitivitas metode multipleks}

Senada dengan hasil simpleks pre-enrichmentPCR, multipleks pre-enrichment-PCR juga menunjukkan sensitivitas yang tinggi atau mampu mendeteksi campuran ketiga serovar dengan jumlah sangat rendah. Hasil perhitungan MPN yang dilakukan untuk konfirmasi jumlah bakteri dari campuran 3 serovar kultur Salmonella dan dispike ke dalam $25 \mathrm{~g}$ karkas ayam (sekitar 0,73 MPN/25 g) 
yang menunjukkan jumlah sel awal yang sangat rendah. Setelah dilakukan multipleks PCR, hasil elektroforesis pada line yang sama menunjukkan kombinasi ukuran pita yang sesuai gen target masingmasing, yaitu 429 bp (Salmonella Hadar, yang mewakili genus Salmonella spp.), 135 bp ( $S$. Enteritidis) dan $311 \mathrm{bp}$ ( $S$. Typhimurium) (Gambar 2). Tahapan pre-enrichment selama 8 jam menunjukkan hasil positif atau dapat terdeteksi pada ketiga jenis target gen (Gambar 2). Oleh karena itu, pada sampel daging ayam yang diduga memiliki cemaran dalam jumlah sangat rendah, tahapan pre-enrichment pada suhu $35^{\circ} \mathrm{C}$ selama 8 jam sebelum deteksi menggunakan multipleks PCR harus dilakukan terlebih dahulu.

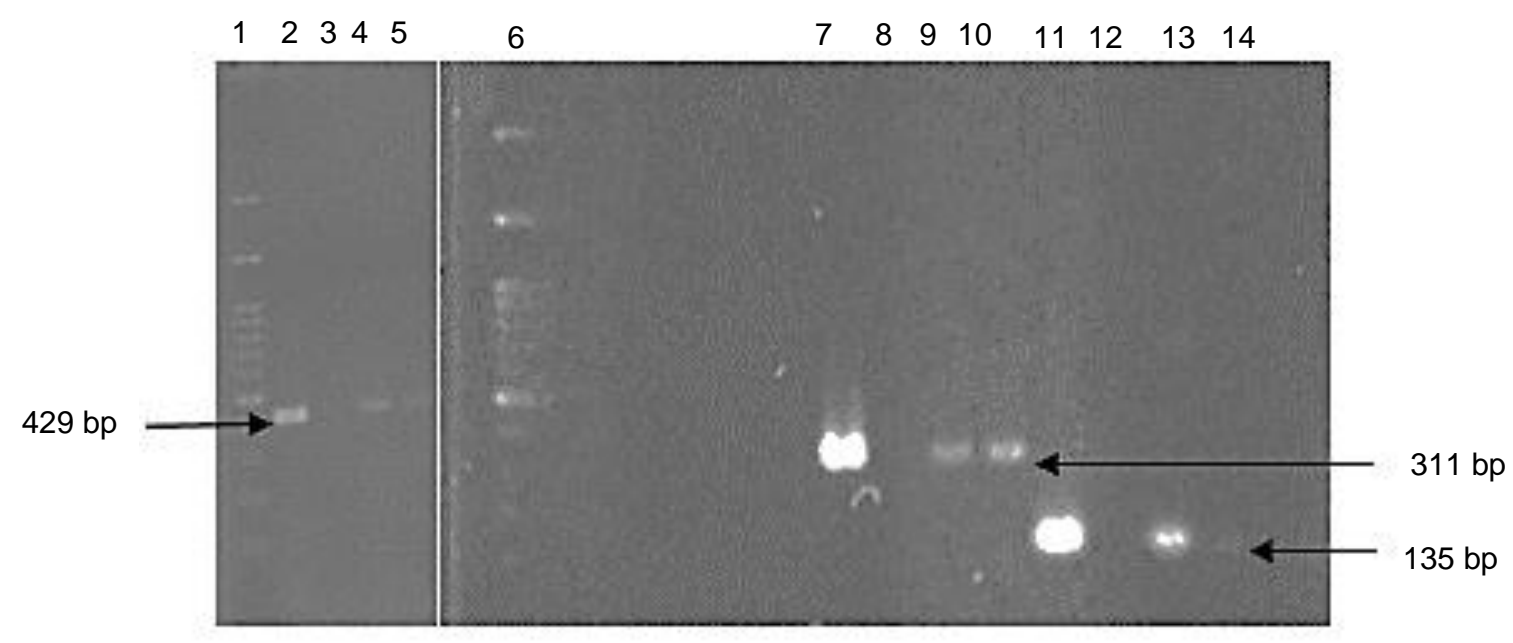

Keterangan: line 1,6= ladder $1200 \mathrm{bp} ; 2-5=$ primer InvA, bakteri $\mathrm{S}$. Hadar, perkiraan konsentrasi bakteri $\left(10^{9} \mathrm{CFU} / 25 \mathrm{~g}\right.$, tanpa bakteri, $10 \mathrm{CFU} / 25 \mathrm{~g}, 1 \mathrm{CFU} / 25 \mathrm{~g}) ; 7-10=$ primer STM4497, bakteri $S$. Typhimurium, perkiraan konsentrasi bakteri $\left(10^{9} \mathrm{CFU} / 25 \mathrm{~g}\right.$, tanpa bakteri, $\left.10 \mathrm{CFU} / 25 \mathrm{~g}, 1 \mathrm{CFU} / 25 \mathrm{~g}\right) ; 11-14=$ primer Prot6E, bakteri $S$. Enteritidis, perkiraan konsentrasi bakteri $\left(10^{9} \mathrm{CFU} / 25 \mathrm{~g}\right.$, tanpa bakteri, $\left.10 \mathrm{CFU} / 25 \mathrm{~g}, 1 \mathrm{CFU} / 25 \mathrm{~g}\right)$

Gambar 1. Visualisasi DNA menggunakan gel elektroforesis hasil uji evaluasi sensitivitas deteksi Salmonella spp. dengan metode simpleks PCR

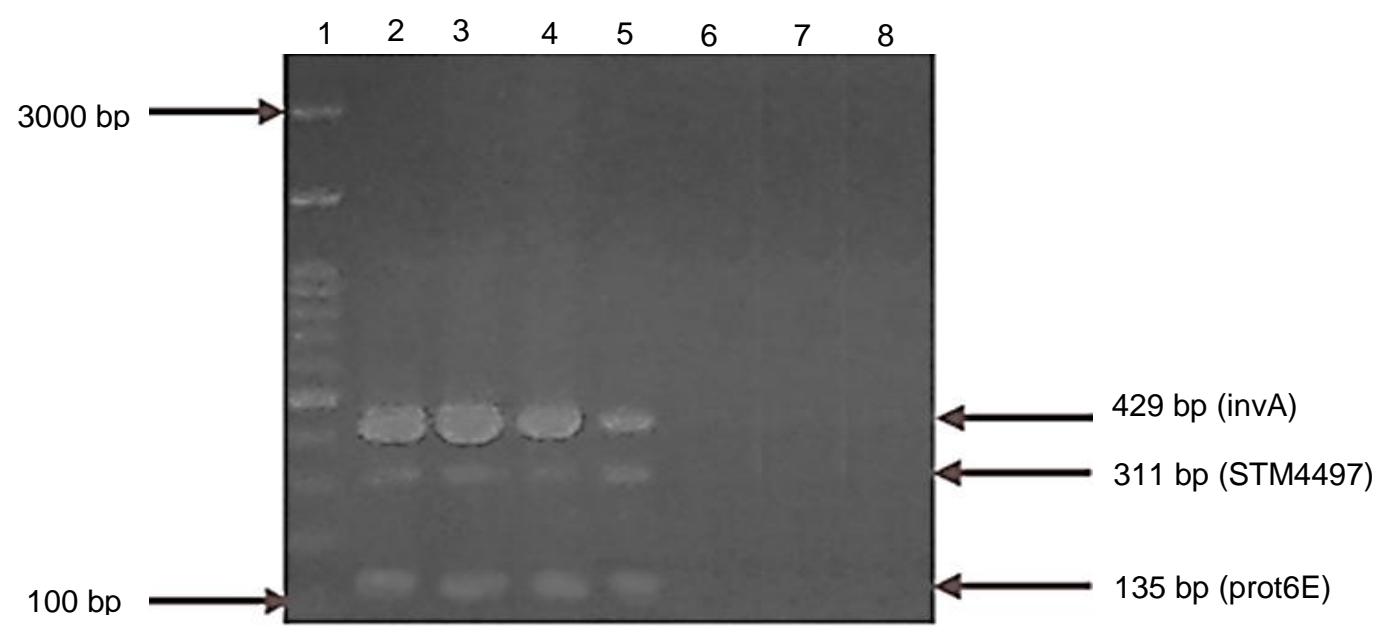

Keterangan: line 1 DNA ladder; 2-5 sampel dengan kontaminasi artifisial perkiraan konsentrasi bakteri $1 \mathrm{CFU} / 25 \mathrm{~g}$ dengan ulangan; 6-8 sampel tanpa kontaminasi artifisial

Gambar 2. Hasil amplifikasi multipleks PCR pada daging ayam yang dikontaminasi artifisial dengan jumlah total Salmonella sangat rendah 
Metode multipleks PCR dapat dipengaruhi oleh beberapa parameter selama analisis termasuk kombinasi primer spesifik dari serovar yang ingin diidentifikasi secara bersamaan, diperlukan desain primer dengan karakteritik kondisi running yang mendekati kondisi primer lainnya yang sudah diketahui (Chiang et al., 2018). Protokol multipleks harus dioptimasi untuk setiap kombinasi gen target, belum ada protokol baku dalam prinsip kerja PCR yang dapat digunakan untuk setiap kondisi terutama dalam metode multipleks PCR (Liu et al., 2012). Kombinasi konsentrasi primer yang digunakan untuk target gen invA sebesar 0,400 $\mu \mathrm{M}$, Prot6E sebesar 0,400 $\mu \mathrm{M}$ dan STM4497 sebesar $0,120 \mu \mathrm{M}$ telah diuji sebelumnya dengan menggunakan template DNA yang berasal dari kultur murni Salmonella serovar dan menghasilkan 3 pita yang spesifik.

\section{Peningkatan presentase hasil positif metode pre- enrichment untuk deteksi Salmonella spp. pada karkas ayam}

Karkas ayam ras digunakan sebagai sampel dalam penelitian ini, karena jumlah produksi dan konsumsi yang lebih tinggi dibandingkan dengan ayam kampung. Kontaminasi Salmonella spp. pada karkas ayam ras dapat terjadi akibat adanya kontaminasi oleh mikroorganisme sebelum ayam dipotong (pencemaran primer) dan sesudah ayam dipotong (pencemaran sekunder) (Aerita et al., 2014). Penyembelihan ayam dianggap sebagai sumber utama kontaminasi Salmonella spp. pada karkas dan kondisi penanganan yang tidak terkontrol de- ngan baik terutama saat karkas ayam dijual dapat menyebabkan meningkatnya jumlah Salmonella spp. yang telah ada sebelumnya (Hoelzer, 2011; ElSharkawy et al., 2017).

Penggunaan metode PCR dengan preenrichment dibandingkan dengan tanpa enrichment dilakukan untuk menganalisis sampel karkas ayam yang sama. Kedua metode ini menunjukkan hasil persentase positif cemaran Salmonella spp. yang berbeda (Gambar 3). Dibandingkan dengan tanpa enrichment, simpleks pre-enrichment-PCR memberikan peningkatan persentase hasil positif. Secara rinci, uji coba metode simpleks pada karkas ayam $(n=12)$ tanpa enrichment dan penggunaan preenrichment masing-masing memberikan hasil positif Salmonella spp., 9 (75\%) dan $12(100 \%)$, positif $S$. Typhimurium 1 (8\%) dan 7 (58\%), dan positif $S$. Enteritidis 7 (58\%) dan 9 (75\%) (Gambar 3). Peningkatan persentase positif juga terjadi pada hasil multipleks pre-enrichment-PCR. Uji coba metode multipleks pada karkas ayam $(n=9)$ tanpa enrichment dan penggunaan pre-enrichment masingmasing memberikan hasil positif Salmonella spp., 7 (77\%) dan $9(100 \%)$ dan positif $S$. Typhimurium 1 (11\%) dan 5 (56\%). Namun kondisi multipleks yang diaplikasikan di dalam sampel dengan kontaminan alami belum menunjukkan kemampuan mendeteksi $S$. Enteritidis secara optimum, diduga karena konsentrasi $S$. Enteritidis di dalam sampel tersebut terlalu rendah, sehingga primer sulit mencapai targetnya.

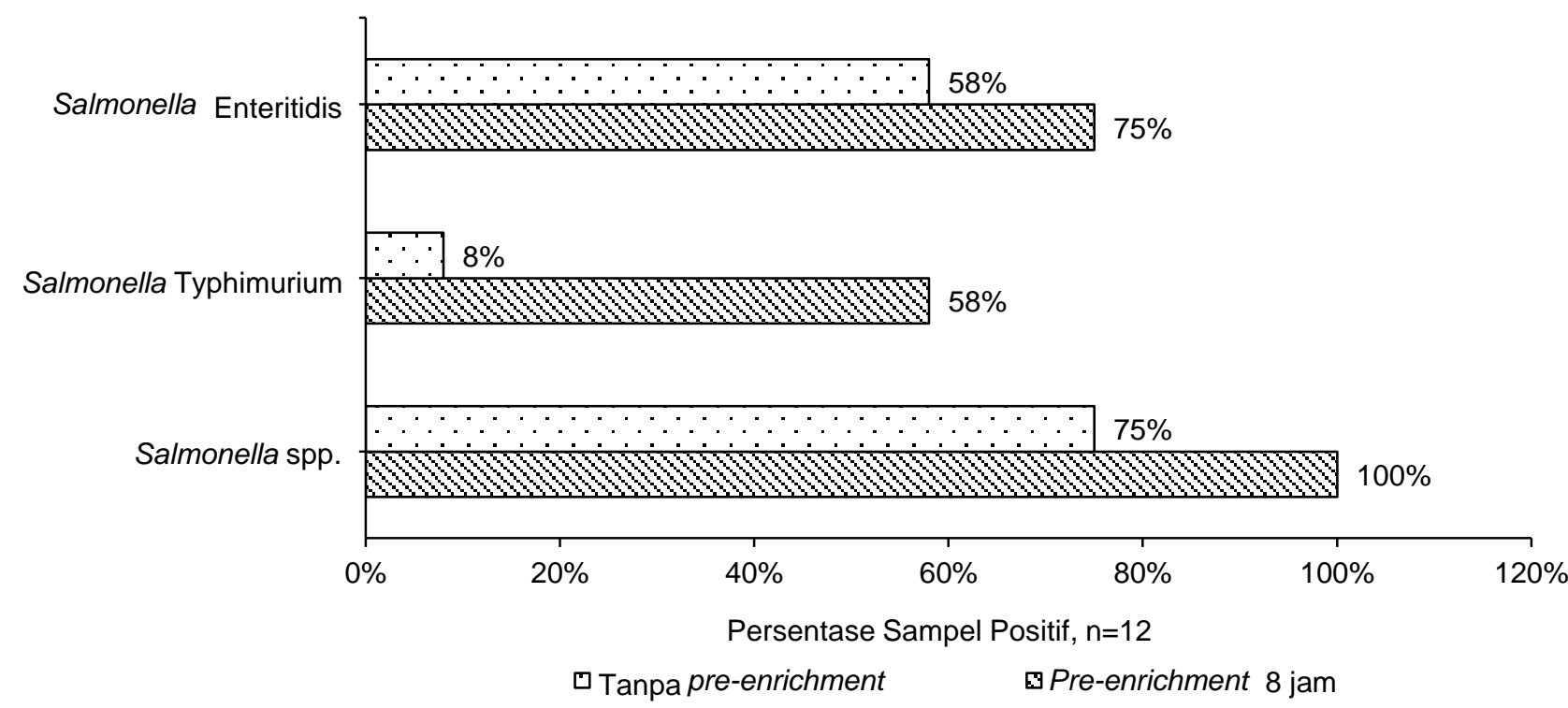

Gambar 3. Perbandingan hasil positif dengan pre-enrichment 8 jam dan tanpa pre-enrichment simpleks PCR deteksi kontaminasi Salmonella spp., $S$. Typhimurium, dan $S$. Enteritidis pada karkas ayam 
Secara umum, penggunaan tahap preenrichment dapat mengurangi false negatif baik pada simpleks maupun menggunakan multipleks. Penggunaan multipleks PCR memberi keuntungan cepatnya hasil deteksi serovar yang berbeda diantara campuran kontaminan Salmonella, tetapi memberikan persentase hasil yang lebih rendah dibandingkan dengan simpleks PCR. Berdasarkan penelitian Gandra et al. (2016), metode multipleks PCR menurunkan sensitivitas deteksi dibandingkan dengan metode simpleks PCR, karena pada multipleks PCR dapat terjadi kompetisi amplifikasi antara satu target gen dengan target gen lainnya sehingga amplifikasi tidak dapat berjalan dengan baik.

Pengujian menggunakan metode multipleks PCR dengan tahap pre-enrichment dapat membantu mendeteksi Salmonella spp., S. Typhimurium dan $S$. Enteritidis dalam jumlah awal yang sangat rendah. Efektifitas metode enrichment dapat ditingkatkan dengan menggunakan medium yang dapat mengeliminasi bakteri Gram negatif lainnya yang masih dapat tumbuh pada media BPW. Keberadaan bakteri Gram negatif lainnya dapat memengaruhi reaksi PCR dan visualisasi pada gel elektroforesis, salah satunya dalam membentuk background pita atau smear (Tran et al., 2013). Kombinasi media dalam tahap enrichment juga direkomendasikan untuk memastikan isolasi berbagai jenis strain dari sampel dengan matriks yang kompleks (Gorsk, 2012).

\section{KESIMPULAN}

Salmonella spp. dengan jumlah rendah $(<3$ $\mathrm{CFU} / 25 \mathrm{~g}$ ) yang diberi perlakuan pre-enrichment dalam media BPW selama 8 jam mampu dideteksi dengan metode PCR. Tahap pre-enrichment penting dilakukan dalam upaya mengurangi kesalahan negatif. Aplikasi metode PCR dengan penambahan tahap pre-enrichment menunjukkan peningkatan hasil positif kontaminasi Salmonella spp.. Dibandingkan dengan tanpa enrichment, simpleks preenrichment-PCR memberikan peningkatan persentase hasil positif Salmonella spp., dari 75 menjadi $100 \%$, positif $S$. Typhimurium dari 8 menjadi $58 \%$, dan positif $S$. Enteritidis dari 58 menjadi $75 \%$. Pada multipleks PCR, penggunaan pre-enrichment memberikan peningkatan hasil positif Salmonella spp., dari 77 menjadi $100 \%$ dan hasil positif $S$. Typhimurium dari 11 menjadi $56 \%$. Namun kondisi multipleks yang dilakukan dalam penelitian ini belum optimum untuk mendeteksi $S$. Enteritidis ketika diaplikasikan ke dalam sampel karkas ayam.

\section{UCAPAN TERIMA KASIH}

Tim Peneliti mengucapkan terima kasih kepada Kementerian Riset, Teknologi, dan Pendidikan Tinggi Republik Indonesia atas pembiayaan penelitian dalam skema hibah Penelitian Dasar Unggulan Perguruan Tinggi (PDUPT) tahun 2019.

\section{DAFTAR PUSTAKA}

Aerita AN, Pawenang ET, Mardiana. 2014. Hubungan higiene pedagang dan sanitasi dengan kontaminasi Salmonella pada daging ayam potong. Unnes J Public Health 3: 9-16.

Afendy ATM, Son R. 2015. Pre-enrichment effect on PCR detection of Salmonella Enteritidis in artifically-contaminated raw chicken meat. Int Food Res J 22: 2571-2576.

Asthiti NGAM. 2019. Peningkatan Sensitivitas Deteksi Cemaran Salmonella spp., S. Typhimurium, dan $S$. Enteritidis menggunakan Multiplex PCR dengan Tahap Pre-enrichment. [skripsi]. Bogor: Fakultas Teknologi Pertanian, Institut Pertanian Bogor.

Bakara VFS, Tafsin M, Hasnudi. 2014. Analisis bakteri Salmonella spp. pada daging ayam potong yang dipasarkan pada pasar tradisional dan pasar modern di Kota Medan. J Peternakan Integratif 3: 71-83. DOI: 10.32734/jpi. v3i1.2746.

Chiang $\mathrm{Y}-\mathrm{C}$, Wang $\mathrm{H}-\mathrm{H}$, Ramireddy L, Chen $\mathrm{H}-\mathrm{Y}$, Shih, C-M, Lin C-K, Tsen H-Y. 2018. Designing a biochip following multiplex polymerase chain reaction for the detection of Salmonella serovars Typhimurium, Enteritidis, Infantis, Hadar, and Virchow in poultry products. J Food Drug Anal 26: 58-66. DOI: 10.1016/j.jfda.2016.11.0 19.

Crump JA, Wain J. 2017. Salmonella. International Encyclopedia of Public Health 2: 425-433. DOI: 10.1016/B978-0-12-803678-5.00394-5.

El-Sharkawy $\mathrm{H}$, Tahoun A, El-Gohary AEGA, ElAbasy M, El-Khayat F, Gillespie T, Kitade Y, Hafez HM, Neubar H, El-Adawy H. 2017. Epidemiological, molecular characterization and antibiotic resistance of Salmonella enterica serovars isolated from chicken farms in Egypt. Gut Pathog 9: 1-12. DOI: 10.1186/s13099-0170157-1.

Eng S-K, Pusparajah P, Ab-Mutalib N-S, Ser H-L, Chan K-G, Lee L-H. 2015. Salmonella: a review on pathogenesis, epidemiology and antibiotic resistance. Front Life Sci 8: 284-293. DOI: 10.1 080/21553769.2015.1051243. 
Gandra EA, Fernandez MA, Silva JA, da Silva WP. 2016. Detection by multiplex PCR of Staphylococcus aureus, $S$. intermedius and $S$. hyicus in artificially contaminated milk. Ciênc Rural 46: 1418-1423. DOI: 10.1590/0103-8478cr201513 91.

Gorski L. 2012. Selective enrichment media bias the types of Salmonella enterica strains isolated from mixed strain cultures and complex enrichment broths. PLoS ONE 7: 1-8. DOI: 10.1371/ journal.pone.0034722.

Hadjinicolaou A, Dmetriou VL, Emmanuel MA, Kakoyiannis CK, Kostrikis LG. 2009. Molecular beacon-based real-time PCR detection of primary isolates of Salmonella Typhimurium and Salmonella Enteritidis in environmental and clinical samples. BMC Microbiol 9: 1-14. DOI: 10. 1186/1471-2180-9-97.

Hoelzer K, Switt AIM, Wiedmann M. 2011. Animal contact as a source of human non-typhoidal salmonellosis. Vet Res 42: 1-28. DOI: 10.1186/1297-9716-42-34.

[ISO] International Organization for Standardization. 2017. ISO 6579:1 Detection of Salmonella spp.. Switzerland $(\mathrm{CH})$ : ISO.

[Kementan RI] Kementerian Pertanian Republik Indonesia. 2020. Statistik Peternakan dan Kesehatan Hewan 2020. Direktorat Jenderal Peternakan dan Kesehatan Hewan, Jakarta.

Krämer N, Löfström C, Vigre H, Hoorfar J, Bunge C, Malorny B. 2011. A novel strategy to obtain quantitative data for modelling: Combined enrichment and real-time PCR for enumeration of salmonellae from pig carcasses. Int $\mathrm{J}$ Food Microbiol 145: 86-96. DOI: 10.1016/j.ijfoodmicro. 2010.08.026.

Liu B, Zhou X, Zhang L, Liu W, Dan X, Shi C, Shi X. 2012. Development of a novel multiplex PCR assay for the identification of Salmonella enterica Typhimurium and Enteritidis. Food Control 27: 87-93. DOI: 10.1016/j.foodcont.201 2.01.062.

Maciel BM, Dias JCT, Romano CC, Sriranganathan N, Brendel M, Rezende RP. 2011. Detection of Salmonella Enteritidis in asymptomatic carrier animals: comparison of quantitative real-time PCR and becteriological cultue methods. Genet Mol Res 10: 2578-2588.

Maksum IP, Suhaili, Amalia R, Kamara DS, Rachman SD, Rachman RW. 2018. PCR Multiplex untuk identifikasi Mycobacterium tuberculosis resisten terhadap isoniazid dan rifampisin pada galur lokal balai laboratorium kesehatan Provinsi Jawa Barat. J Kimia Valensi 4: 107118. DOI: 10.15408/jkv.v4i2.7226.
Matias BG, Pinto PSA, Cossi MVC, Silva JA, Vanetti MCD, Nero LA. 2010. Evaluation of a PCR protocol for the detection of Salmonella species directly from superficial samples of chicken carcasses and pre-enrichment broth. Poultry Sci 89: 1524-1529. DOI: 10.3382/ps.2009-003 68.

Myint MS, Johnson YJ, Tablante NL, Heckert RA. 2006. The effect of pre-enrichment protocol on the sensitivity and specificity of PCR for detection of naturally contaminated Salmonella in raw poultry compared to conventional culture. Food Microbiol 23: 599-604. DOI: 10.1016/j.fm.2005. 09.002

Nurjanah S, Rahayu WP, Komalasari E. 2017. Sensitivity of multiplex real-time PCR assay for detection of pathogenic $E$. coli on ice sample. November 14-17 2017. Ho Chi Minh City, Vietnam. Ho Chi Minh City (VI): Proceedings of the 15th ASEAN Conference on Food Science and Technology.

Nurjanah S, Rahayu WP. Mutaqin LA. 2018. Detection method for Salmonella Typhimurium and Salmonella Enteritidis using real-time polymerase chain reaction. Int J Eng Technol 7: 302-306. DOI: 10.14419/ijet.v7i4.14.27661.

Park SH, Kim HJ, Cho WH, Kim JH, Oh MH, Kim SH, Lee BK, Ricke SC, Kim HY. 2009. Identification of Salmonella enterica subspecies I, Salmonella enterica serovars Typhimurium, Enteritidis and Typhi using multiplex PCR. FEMS Microbiol Lett 30: 137-146. DOI: 10.1111/j.1574-6968.20 09.01809.x.

Radji M, Puspaningrum A, Sumiati A. 2010. Deteksi cepat bakteri Escherichia coli dalam sampel air dengan metode polymerase chain reaction menggunakan primer $16 \mathrm{e} 1$ dan 16e2. Makara J Sci 14: 39-43. DOI: 10.7454/mss.v14i1.474.

Reyes-Escogido L, Balam-Chi M, Rodriguez-Buenfil I, Valdés J, Kameyama L, Martinez-Pérez F. 2010. Purification of bacterial genomic DNA in less than 20 mins using chelex-100 microwave: examples from stains of lactic acid bacteria isolated from soil samples. Anton Leeuw 98: 465-474. DOI: 10.1007/s10482-010-9462-0.

Saeki EK, Alves J, Bonfante RC, Hirooka EY, de Oliveira TCRM. 2012. Multiplex PCR (mPCR) for detection of Salmonella spp. and the differentiation of Typhimurium and Enteritidis serovars in chicken meat. J Food Safety 33: 25-29. DOI: $10.1111 /$ jfs. 12019.

Safitri E, Hidayati NA, Hertati R. 2019. Prevalensi bakteri Salmonella pada ayam potong yang dijual di pasar tradisional pangkalpinang. Ekotomia: J Penelitian Biologi, Botani, Zoologi, 
dan Mikrobiologi 4: 25-30. DOI: 10.33019/ ekotonia.v4i1.1012.

Soumet C, Ermel G, Rose N, Rose V, Drouin P, Salvat G, Colin P. 1999. Evaluation of multiplex PCR assay for simultaneous identification of Salmonella spp., Salmonella Enteritidis and Salmonella Typhimurium from environmental swabs of poultry houses. Lett Appl Microbiol 28: 113-117. DOI: 10.1046/j.1365-2672.1999.0048 8.x.

Taskila S, Tuomola M, Ojamo H. 2012. Enrichment cultivation in detection of food-borne Salmonella. Food Control 26: 369-377. DOI: 10.1016/ j.foodcont.2012.01.043.

Tortajada-Genaro LA, Rodrigo A, Hevia E, Mena S, Niñoles R, Maquieira A. 2015. Microarray on digital versatile disc for identification and genotyping of Salmonella and Campylobacter in meat products. Anal Bioanal Chem 407: 72857294. DOI: $10.1007 / \mathrm{s} 00216-015-8890-0$

Tran HH, Trinh KTL, Lee NY. 2013. Pressure-driven one-step solid phase-based on-chip sample preparation on a microfabricated plastic device and integration with flow-through polymerase chain reaction (PCR). J Chromatogr B 936: 8894. DOI: 10.1016/j.jchromb.2013.06.037.
Triyani Y, Nafsi N, Yuniarti L, Sekarwana N, Sutedja E, Gurnida DA, Parwati I, Alisjahbana B. 2016. Rancangan primer spesifik gen macrophage mannose receptor (MMR) untuk Polymerase Chain Reaction (PCR) dan sekuensing Deoxyribose Nucleic Acid (DNA). Indonesian J Clin Pathol Med Lab 22: 158-162. DOI: 10.24293/ ijcpml.v22i2.1120.

Utari LK, Riyanti, Santosa PE. 2016. Status mikrobiologis daging broiler di pasar tradisional kabupaten Pringsewu. J IImiah Peternakan Terpadu 4: 63-66.

Wulan HA, Nurjanah S, Rahayu, WP. 2021. Sensitivity of enrichment-PCR method for Salmonella enterica serovar Typhimurium and Salmonella enterica serovar Enteritidis analysis in chicken carcasses. Food Res 5: 54-61. DOI: 10.26656/ fr.2017.5(2).429.

Yosua A. 2018. Deteksi Salmonella Hadar, Salmonella Typhimurium, dan Salmonella Enteritidis menggunakan Polymerase Chain Reaction (PCR). [Skripsi]. Bogor: Fakultas Teknologi Pertanian, Institut Pertanian Bogor.

[WHO] World Health Organization. 2014. WHO Global Salmonella survey: Progress Report 2008-2013. World Health Organization. 